\title{
PSYCHOLOGY
}

\section{ЗАСТОСУВАННЯ МЕТОДІВ ЛОГІСТИКИ В ПСИХОЛОГІї РОЗВИТКУ ДИТИНИ}

${ }^{1}$ Ст. викладач Піддубна Н. М.,

${ }^{2}$ Студентка Коваленко Ю. Ю.

${ }^{I}$ Украйна, Одеса, Одеський наиіональний морський університет,

Навчально-Науковий Інститут Морського Бізнесу,

Кафедра Управління логістичними системи і проектами

${ }^{2}$ Україна, Одеса, Одеський морський університет,

Навчально-Науковий Морський Гуманітарний Інститут

DOI: https://doi.org/10.31435/rsglobal_ijitss/30062019/6538

\section{ARTICLE INFO}

Received 28 April 2019

Accepted 19 June 2019

Published 30 June 2019

\section{KEYWORDS}

logistic approach, child development psychology, knowledge flow.

\begin{abstract}
In work the possibility of applying a logistic approach in educational psychology is considered. Justification of the choice of preschool age child development is a very relevant task and the subject of study of many scientists - psychologists. The work contains proposition to consider coming information as the streaming process and, accordingly, to rationalize the development system by optimizing the flow of knowledge. To justify the possible direction of child's development, it is proposed to use the method of analytical hierarchies, which allows to make decisions for multicriterial tasks.

Experimental calculations based on the initial data, obtained by the observation method, allowed to make recommendations on further direction of the "chosen" knowledge flow for development of the child in accordance with his individual abilities.
\end{abstract}

Citation: Піддубна Н. М., Коваленко Ю. Ю. (2019) Zastosuvannia Metodiv Lohistyky v Psykholohii Rozvytku Dytyny. International Journal of Innovative Technologies in Social Science. 4(16). doi: 10.31435/rsglobal_ijitss/30062019/6538

Copyright: (C) 2019 Піддубна Н. М., Коваленко Ю. Ю. This is an open-access article distributed under the terms of the Creative Commons Attribution License (CC BY). The use, distribution or reproduction in other forums is permitted, provided the original author(s) or licensor are credited and that the original publication in this journal is cited, in accordance with accepted academic practice. No use, distribution or reproduction is permitted which does not comply with these terms.

Вступ. Актуальність дослідження викликана впровадженням, останнім часом, ідеї особистісно-орієнтованого розвитку дітей. Для обгрунтування вибору напрямку розвитку необхідно досліджувати великий обсяг інформації. Представляючи інформацію як потік знань можливо використовувати принципи і методи логістики, як науки і практики, що вивчає потокові процеси.

В останні роки в психології розглядається суб'єктивний підхід, в якому людина $\epsilon$ активним суб'єктом власного життя, перетворює сама себе і свій життєвий простір, відповідальна за свій вибір в різних життєвих ситуаціях і особистісний розвиток. Такий підхід прийнятний для дорослої людини, що вже має життєві стремління. I завдання, яке стоїть перед ним - це вибір обгрунтованого альтернативного розвитку.

Проблема життєвого вибору розглядалася в працях [1], де представлені рекомендації 3 розвитку особистісних, пізнавальних, регулятивних i комунікативних універсальних навчальних дій, спрямованих на формування у дітей вміння вчитися. Праця [2] в основному присвячена теоретичному і практичному підходу психологічного консультування, на основі наявних фактів про особистості.

В [3] приділяється увага основним типам психолого-педагогічної взаємодії між різними суб'єктами освітнього середовища. Особистість, як складна система, що самоорганізується та 
як відкрита система, представляється в праці [4] і проблеми життєвого вибору здійснюються «коли людина розуміє сенс і цінність своїх дій».

Як ми бачимо, з представленого аналізу, питання вибору в психології вже розглядалося, але треба відзначити, що на сьогодні це питання недостатньо вивчено, оскільки не наводиться якогось формалізованого апарату для оцінки особистості.

Результати дослідження. Сьогодні впровадження методів психології в освітній процес дитини, шляхом створення стратегії розвитку особистості, стає одним із головних завдань теоретичної та практичної психології.

Психологія розвитку - це галузь психології, яка вивчає психологічні зміни людини, зокрема дитини, у міру того, як вона дорослішає.

Виходячи 3 того, що предметом вивчення психології розвитку дитини $є$ формування особистісних якостей в різні періоди його дорослішання, можна констатувати, що основним завданням психології розвитку $є$ розкриття основних особливостей розвитку конкретної особистості через опис його індивідуальних здібностей.

Виходячи з розглянутих задач, можна виділити функції психології розвитку:

- описова функція - описує особливості розвитку дитини в різні вікові періоди з точки зору зовнішніх проявів;

- пояснювальна функція - допомагає зрозуміти причини, чинники і умови змін в поведінці людини;

- прогнозуюча функція - прогнозує зміни в поведінці дитини на кожному віковому етапі;

- коригувальна функція - створює оптимальні умови для управління розвитком дитини.

3 метою вирішення поставленого завдання в психології використовуються загальнонаукові і загальнопсихологічні методи. Всі методи психології розвитку можна розділити на кілька категорій: загальнонаукові методи, психогенетичні, психофізіологічні, історичні та психологічні.

Загальнонаукові методи представляють особливу модифікацію методів, які використовуються в багатьох інших наукових дисциплінах і включають спостереження (вивчення дитини на основі результатів, об'єктивної оцінки) і експеримент (цілеспрямована зміна однієї або декількох змінних і спостереження за результатами цієї зміни).

Психогенетичні методи спрямовані на виділення факторів середовища і спадковості індивідуальних психологічних якостей дитини.

Психофізіологічні методи вивчають роботу нервової системи дитини.

Історичні методи вивчають життевий шлях дитини, особливості спадковості i середовища, які створили особливі передумови для його духовного становлення.

Психологічні методи поділяють на дві підгрупи: інтроспективні (збір інформації про об'єкт вивчення) і соціально-психологічні (бесіда, інтерв'ю, анкетування, тестування).

Окремою категорією виділяють метод моделювання. Під моделюванням в психології розуміють відтворення певної психічної ситуації. Такий метод застосовується в психології для того, щоб отримати більш точні дані про психіку досліджуваної дитини, особливості іiі поведінки в певних ситуаціях і при певних умовах, а також іiі реакції на них.

3 нашої точки зору, для формування і розвитку індивідуальних здібностей дитини 3 метою проектування іiі на подальший вибір спеціальності, необхідно розширити наявні методи i підходи в психології і зокрема, метод моделювання, можливо, розвинути до застосування математичного апарату.

Як розглянуто вище, психологія розвитку дитини оперує достатньою кількістю методів і всі вони застосовуються відособлено, несистемно. Тобто, кожен з методів використовується для оцінки певних параметрів і на основі цих оцінок формуються певні висновки, в результаті яких застосовуються прописані дії для вирішення даної проблеми.

В енциклопедичному словнику «система» (від грец. Systema - ціле, складене з частин, з'єднання) визначається «як множина елементів, що знаходяться у відносинах і зв'язках один 3 одним, утворюють певну цілісність, єдність».

Оскільки об'єктом цього дослідження $€$ розвиток дитини у відповідності 3 індивідуальними здібностями, будемо розглядати його, як особливий вид системи, яка з часом формується і перебудовується. Результат формування системи (дитини) буде залежати від того, які потоки інформації будуть спрямовані до неї.

Відомо, що потокові процеси - це об'єкт дослідження такого наукового напрямку як логістика. Відбулося становлення логістики як науки про управління матеріальними, 
фінансовими та інформаційними потоками. За допомогою їі методів вдається синхронізувати переміщення матеріальних ресурсів від сировини до виробництва, через склади і до утилізації продуктів, які завершили свій життєвий цикл. Внаслідок цього різко скорочується запаси сировини, готових виробів. Це значно сприяє економії капіталу.

3 нашої точки зору, проблема вибору напрямку розвитку дитини, можливо будувати на логістичному підході, який в нашому випадку буде базуватися на раціоналізації системи розвитку шляхом оптимізації потоку знань. Під потоком знань будемо розуміти ту інформацію, яка необхідна в потрібних кількостях в даний час для розвитку саме тих якостей, до яких схильна дитина, з можливо мінімальними часовими і фінансовими витратами. Тоді психологічний потік знань може бути визначений як знання, що передаються дитині на основі ії індивідуальних здібностей.

Питання управління знаннями розглядалися і раніше, але виключно як процес. У 90 роках минулого століття з'явилася нова концепції - «knowledge management», згідно з якою, як зазначено в [5], під керуванням знаннями розуміється «процес збору, поширення та ефективне використання знань". 3 точки зору авторів даної концепції «основна суть системи управління знаннями полягає в зборі та фіксації інформації і знань, якими володіють співробітники, і в поширенні цих знань між усіма членами колективу». Відповідно і до процесу управління знаннями застосовувалися процесні методи:

1. Better Practice Transfer - використовують в процесі опису процесу розробки передачі знання. Серед основних завдань можна назвати організацію, створення, збирання та поширення знань, включаючи забезпечення їх доступності майбутнім користувачам.

2. Boundary Examination - метод, що припускає поліпшення формулювання проблем 3 метою збільшення ясності завдання, визначення важливих і неважливих аспектів.

3. «Класичний» мозковий штурм $є$ розробкою великого числа ідей за допомогою колективних обговорень.

Розгляд знань як потоковий процес дозволить включити в систему управління знаннями не тільки завдання зі збору, розгляду та поширенню знань, а й застосувати логістичні методи, що дозволяють оптимізувати збір інформації і орієнтувати іiї на конкретного споживача з метою ефективного розвитку його знань.

Такий підхід виправданий, оскільки фахівці відзначають, що існуюча практика передачі великого обсягу знань «про всяк випадок» вже не відповідає реальності, тобто потребується вдосконалення відбору необхідної кількості знань, виходячи з поставленої мети.

Застосування логістичного підходу до вибору напрямку розвитку дитини передбачає, як говорилося вище, не тільки використання системного підходу, а й адаптації відомих методів i моделей логістики.

В даному випадку під адаптацією будемо розуміти додання принципів і методів логістики до психологічного потоку знань у поєднанні з методами, використовуваними в психології.

Як показав аналіз літературних джерел, вузьким місцем у розвитку дитини є правильна, позбавлена суб'єктивізму оцінка його здібностей. 3 цією метою, пропонуємо використовувати метод аналізу ієрархій (MAI), який часто використовується в рішенні багатокритеріальних задачах логістики. Мета цього методу в завданні розвитку дитини зводиться до виділення пріоритетного напрямку, куди в подальшому будуть направлені потоки відповідних знань. Тим самим буде досягнута концентрація зусиль в розвитку.

Метод аналізу ієрархій (MAI) є логічною конструкцією, яка забезпечує за допомогою простих правил аналіз складних проблем у всьому їх різноманітті і приводить до найкращої відповіді. Застосування методу дозволяє включити в ієрархію всі наявні в дослідника 3 даної проблеми знання і уяву.

Зрозуміло, що математично формули не можуть замінити людський розум і досвід інтерпретації реального світу. Однак, за допомогою уявлення реального світу у вигляді математичних символів i залежностей, можливо систематизувати знання про об'єкт i прогнозувати розвиток об'єкта в майбутньому. MAI дозволяє групі людей взаємодіяти з певної проблеми, модифікувати свої судження і в результаті об'єднати групові судження відповідно до основних критеріїв: при проведенні попарних порівнянь об'єктів по відношенню до деякої характеристики, або характеристик по відношенню до вищої мети; зворотні відносини забезпечують ключ до об'єднанню групових суджень раціональним чином.

Даний метод дозволяє показати те, що видається природнім ходом людського мислення. Стикаючись з безліччю контрольованих або неконтрольованих елементів, що відбивають складну ситуацію, розум об'єднує їх в групи відповідно до розподілу деяких властивостей між елементами. 
MAI повторює процес мислення при виборі альтернатив таким чином, що групи, або скоріше виокремлюючи їх загальні властивості, розглядаються в якості елементів рівнів системи. Ці елементи, в свою чергу, групуються відповідно до іншого набору властивостей, створюючи елементи ще одного, більш високого рівня, і так до тих пір, поки не буде досягнутий єдиний елемент - вершина, яку часто можна ототожнити з метою процесу прийняття рішень. Такий процес називають ієрархією, тобто системно нашаровуються рівні, кожен 3 яких складається 3 багатьох елементів, або факторів. Основним завданням в ієрархії є виявлення, наскільки сильно впливають окремі чинники найнижчого рівня ієрархії на вершину - спільну мету. Визначення пріоритетів чинників нижчого рівня щодо мети може бути зведено до послідовності задач, визначення пріоритетів для кожного рівня, а кожна така задача - до послідовності попарних порівнянь. Порівняння залишаються основними складовими теорії MAI, навіть якщо вихідна задача ускладнена умовами зворотного зв'язку між різними рівнями або факторами.

Як вказує автор методу [6], MAI дозволяє розглядати проблеми конфліктів в групі людей, що мають спільні цілі; між конкуруючими організаціями і навіть між різними країнами (з залученням посередника). Тому, з нашої точки зору, можливо і доцільно адаптувати дану методику в галузь психології i, зокрема, до проблеми розгляду розвитку дитини.

Метод аналітичних ієрархій полягає в попарному порівнянні критеріїв $\mathrm{C}_{\mathrm{i}}(\mathrm{i}=1, \ldots, \mathrm{n})$, i також альтернатив $\mathrm{A}_{\mathrm{k}}(\mathrm{k}=1, \ldots, \mathrm{m})$ за критеріями із застосуванням відносини переваги. Результати зводяться в таблиці, загальний вигляд яких наведено в таблиці 1.

Таблиця 1. Загальний вигляд таблиць попарного порівняння критеріїв і альтернатив

\begin{tabular}{|c|c|c|c|c|c|c|}
\hline & \multicolumn{4}{|c|}{ Критерії } & \multirow{2}{*}{$\begin{array}{l}\text { Особистий } \\
\text { вектор }\end{array}$} & \multirow{2}{*}{$\begin{array}{l}\text { Вага } \\
\text { критерія }\end{array}$} \\
\hline & $\mathrm{C}_{1}$ & $\mathrm{C}_{2}$ & $\ldots$ & $\mathrm{C}_{\mathrm{n}}$ & & \\
\hline $\mathrm{C}_{1}$ & $\mathrm{C}_{11}$ & $\mathrm{C}_{12}$ & $\ldots$ & $\mathrm{C}_{1 \mathrm{n}}$ & $\mathrm{K}_{1}$ & $\alpha_{1}$ \\
\hline 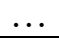 & 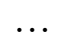 & & $\ldots$ & 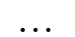 & & $\ldots$ \\
\hline $\mathrm{C}_{\mathrm{n}}$ & $\mathrm{C}_{\mathrm{n} 1}$ & $\mathrm{C}_{\mathrm{n} 2}$ & & $\mathrm{C}_{\mathrm{nn}}$ & $\mathrm{K}_{\mathrm{n}}$ & $\alpha_{2}$ \\
\hline
\end{tabular}

Розглянемо алгоритм розв'язання задачі.

Заповнюють комірки таблиць за наступною схемою:

1. $\quad \mathrm{C}_{\mathrm{ii}}=1(\mathrm{i}=1, . ., \mathrm{n} ; \mathrm{j}=1, \ldots, \mathrm{n})$;

2. Якщо критерій $\mathrm{C}_{\mathrm{i}}$ перевершує за важливістю критерій $\mathrm{C}_{\mathrm{j}}, C i j=\{1,3,5,7,9\}$, аналогічно оцінюються альтернативи. Тут 1 означає рівність, 3 - помірну перевагу, 5 - істотну перевагу, 7 - значну перевагу, 9 - дуже велику перевагу;

3. Для домінуючих альтернатив записують зворотні значення:

$$
C j i=\frac{1}{C i j} \text {; }
$$

4. Розраховують значення власного вектора за формулою:

$$
K_{i}^{\circ \sigma \circ \sigma}=\sqrt[n]{\prod_{1}^{n} K_{i}}
$$

5. Згідно формули (4) розраховують вагу критерію:

$$
\alpha_{i}=\frac{K_{i}^{000 \delta}}{\sum_{i}^{n} K_{i}^{000 \delta}} .
$$

6. Далі формують зведену таблицю ваги критеріїв i розраховують інтегральний показник для кожної альтернативи за формулою (5):

$$
R_{i}=\sum_{1}^{n} \alpha_{i} \gamma_{i j}, \text { где } \gamma_{i j}(j=1, \ldots, m) .
$$

7. В якості оптимальної вибирають ту альтернативу, для якої інтегральний показник $€$ найбільшим:

$$
R=\max _{i}\left\{R_{i}\right\}
$$

Розглянемо на прикладі методику формування напрямку розвитку дитини, засновану на використанні методу МАI.

Відповідно до теорії МАI, для оцінки суджень виділяють критерії і субкритерії, які ведуть до вибору альтернатив. Тому треба розуміти, що, застосовуючи даний метод, фахівець самостійно вибудовує ієрархію і кількість критеріїв залежить від його вибору і наявності достовірної інформації.

Для легкого сприйняття розглянемо ієрархічну систему, що складається з трьох рівнів: мета, критерії та альтернативи.

Вищим рівнем ієрархії (метою) приймемо ідентифікації майбутнього напрямку розвитку дитини дошкільного віку. Під напрямком розвитку будемо розуміти виявлення природних і вже 
розвинених здібностей дитини. Візьмемо до уваги, що основними факторами розвитку дитини $\epsilon$ спадковість, середовище і виховання. Дитина від народження наділена природними задатками (передумовами до того чи іншого виду діяльності). Саме види профільної освіти вважатимемо факторами третього рівня (альтернативами). Критеріями другого рівня є здібності дитини, його зацікавленість в чому-небудь, тип особистості і т.д. Наведемо схему розглянутої ієрархії на рисунку 1.

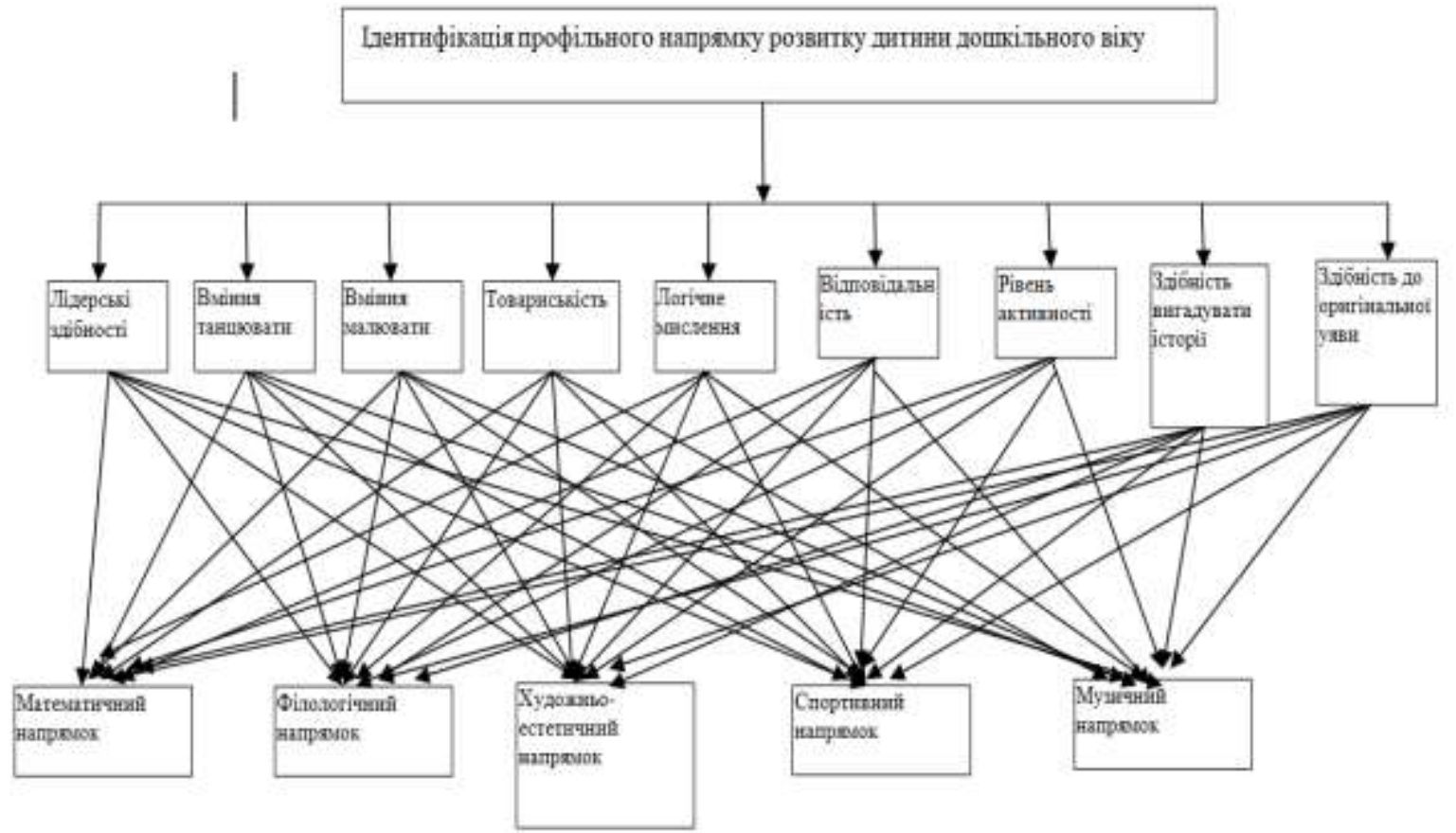

Рис. 1 Декомпозиція мети вибору напрямку розвитку дитини

Вихідними даними в даній задачі є оцінки дитини за критеріями $\left(\mathrm{c}_{\overline{i j}}\right)$, отримані методом спостереження. Оцінка проводилася експертами за 100 бальною шкалою.

До критеріїв відносяться наступні: Лідерські здібності $\left(\mathrm{C}_{1}\right)$ - 80, Вміння танцювати $\left(\mathrm{C}_{2}\right)$ - 20, Вміння малювати $\left(\mathrm{C}_{3}\right)-50$, Товариськість $\left(\mathrm{C}_{4}\right)-70$, Логічне мислення $\left(\mathrm{C}_{5}\right)-60$, Відповідальність $\left(\mathrm{C}_{6}\right)-90$, Рівень активності $\left(\mathrm{C}_{7}\right)-60$, Здатність вигадувати історії $\left(\mathrm{C}_{8}\right)-20$, Оригінальна уява $\left(\mathrm{C}_{9}\right)-70$.

Згідно алгоритму проводимо порівняння критеріїв (табл. 2)

Далі, спираючись на вихідні дані, порівнюємо альтернативи щодо запропонованих критеріїв (табл. 3-12).

Таблиця 2. Попарне порівняння критеріїв відносної важливості

\begin{tabular}{|l|l|l|l|l|l|l|l|l|l|l|l|}
\hline & $\mathrm{C}_{1}$ & $\mathrm{C}_{2}$ & $\mathrm{C}_{3}$ & $\mathrm{C}_{4}$ & $\mathrm{C}_{5}$ & $\mathrm{C}_{6}$ & $\mathrm{C}_{7}$ & $\mathrm{C}_{8}$ & $\mathrm{C}_{9}$ & $\mathrm{~K}_{i}^{\text {особ }}$ & $\alpha \mathrm{i}$ \\
\hline $\mathrm{C}_{1}$ & 1,00 & 8,00 & 4,00 & 2,00 & 4,00 & 0,33 & 4,00 & 9,00 & 2,00 & 2,63596 & 0,28113 \\
\hline $\mathrm{C}_{2}$ & 0,13 & 1,00 & 0,20 & 0,14 & 0,20 & 0,11 & 0,20 & 1,00 & 0,20 & 0,24495 & 0,02612 \\
\hline $\mathrm{C}_{3}$ & 0,25 & 5,00 & 1,00 & 0,33 & 0,50 & 0,20 & 0,50 & 3,00 & 0,33 & 0,65042 & 0,06937 \\
\hline $\mathrm{C}_{4}$ & 0,50 & 7,00 & 3,00 & 1,00 & 2,00 & 0,33 & 2,00 & 7,00 & 1,00 & 1,66436 & 0,17750 \\
\hline $\mathrm{C}_{5}$ & 0,25 & 5,00 & 2,00 & 0,50 & 1,00 & 0,33 & 1,00 & 5,00 & 0,50 & 1,00454 & 0,10713 \\
\hline $\mathrm{C}_{6}$ & 3,00 & 9,00 & 5,00 & 3,00 & 3,00 & 1,00 & 5,00 & 9,00 & 4,00 & 3,92027 & 0,41811 \\
\hline $\mathrm{C}_{7}$ & 0,25 & 0,50 & 2,00 & 0,50 & 1,00 & 0,20 & 1,00 & 6,00 & 0,20 & 0,67731 & 0,07223 \\
\hline $\mathrm{C}_{8}$ & 0,11 & 1,00 & 0,33 & 0,14 & 0,20 & 0,11 & 0,17 & 1,00 & 0,14 & 0,24155 & 0,02576 \\
\hline $\mathrm{C}_{9}$ & 0,50 & 5,00 & 3,00 & 1,00 & 2,00 & 0,25 & 2,00 & 7,00 & 1,00 & 1,55284 & 0,16562 \\
\hline
\end{tabular}


Таблиця 3. Порівняння альтернатив щодо критерію «Лідерські здібності»

\begin{tabular}{|c|c|c|c|c|c|c|c|}
\hline Альтернативы & $\mathrm{A}_{1}$ & $\mathrm{~A}_{2}$ & $\mathrm{~A}_{3}$ & $\mathrm{~A}_{4}$ & $\mathrm{~A}_{5}$ & $\mathrm{~K}_{i}^{0006}$ & $\gamma_{i j}$ \\
\hline $\mathrm{A}_{1}$ & 1 & 2 & 3 & 0,33333 & 0,2 & 0,83255 & 0,13224 \\
\hline $\mathrm{A}_{2}$ & 0,5 & 1 & 3 & 0,25 & 0,2 & 0,59567 & 0,09462 \\
\hline $\mathrm{A}_{3}$ & 0,33333 & 0,333333 & 1 & 0,5 & 0,2 & 0,40658 & 0,06458 \\
\hline $\mathrm{A}_{4}$ & 3 & 4 & 2 & 1 & 3 & 2,35215 & 0,37363 \\
\hline $\mathrm{A}_{5}$ & 5 & 5 & 5 & 0,33333 & 1 & 2,10842 & 0,33491 \\
\hline & & & & & сума & 6,29539 & \\
\hline
\end{tabular}

Таблиця 4. Порівняння альтернатив щодо критерію «Вміння танцювати»

\begin{tabular}{|c|c|c|c|c|c|c|c|}
\hline Альтернативы & $\mathrm{A}_{1}$ & $\mathrm{~A}_{2}$ & $\mathrm{~A}_{3}$ & $\mathrm{~A}_{4}$ & $\mathrm{~A}_{5}$ & $\mathrm{~K}_{i}^{\text {oco6 }}$ & $\gamma_{i j}$ \\
\hline $\mathrm{A}_{1}$ & 1 & 0,111111 & 0,11111 & 0,125 & 0,125 & 0,18074 & 0,02532 \\
\hline $\mathrm{A}_{2}$ & 9 & 1 & 0,125 & 0,2 & 9 & 1,15155 & 0,16133 \\
\hline$A_{3}$ & 9 & 8 & 1 & 3 & 1 & 2,93015 & 0,41051 \\
\hline $\mathrm{A}_{4}$ & 8 & 5 & 0,33333 & 1 & 3 & 2,09127 & 0,29298 \\
\hline $\mathrm{A}_{5}$ & 8 & 0,111111 & 1 & 0,33333 & 1 & 0,78405 & 0,10984 \\
\hline & & & & & сума & 7,13778 & \\
\hline
\end{tabular}

Таблиця 5. Порівняння альтернатив щодо критерію «Вміння малювати»

\begin{tabular}{|c|c|c|c|c|c|c|c|}
\hline Альтернативы & $\mathrm{A}_{1}$ & $\mathrm{~A}_{2}$ & $A_{3}$ & $\mathrm{~A}_{4}$ & $\mathrm{~A}_{5}$ & $\mathrm{~K}_{i}^{\text {oco6́ }}$ & $\gamma_{i j}$ \\
\hline $\mathrm{A}_{1}$ & 1 & 3 & 0,125 & 3 & 3 & 1,27542 & 0,16142 \\
\hline $\mathrm{A}_{2}$ & 0,333333 & 1 & 0,2 & 9 & 0,33333 & 0,72478 & 0,091729 \\
\hline $\mathrm{A}_{3}$ & 8 & 5 & 1 & 9 & 7 & 4,78938 & 0,606152 \\
\hline $\mathrm{A}_{4}$ & 0,333333 & 0,111111 & 0,111111 & 1 & 0,33333 & 0,26758 & 0,033865 \\
\hline $\mathrm{A}_{5}$ & 0,33333 & 3 & 0,14285 & 3 & 1 & 0,84412 & 0,106833 \\
\hline & & & & & сума & 7,90129 & \\
\hline
\end{tabular}

Таблиця 6. Порівняння альтернатив щодо критерію «Товариськість»

\begin{tabular}{|c|c|c|c|c|c|c|c|}
\hline Альтернативы & $\mathrm{A}_{1}$ & $\mathrm{~A}_{2}$ & $\mathrm{~A}_{3}$ & $\mathrm{~A}_{4}$ & $\mathrm{~A}_{5}$ & $K_{i}^{0006}$ & $\gamma_{i j}$ \\
\hline $\mathrm{A}_{1}$ & 1 & 0,2 & 0,5 & 0,5 & 0,5 & 0,47817 & 0,06433 \\
\hline $\mathrm{A}_{2}$ & 5 & 1 & 5 & 3 & 5 & 3,27194 & 0,44022 \\
\hline $\mathrm{A}_{3}$ & 2 & 0,2 & 1 & 0,5 & 0,33333 & 0,58181 & 0,07828 \\
\hline $\mathrm{A}_{4}$ & 2 & 5 & 2 & 1 & 3 & 2,267933 & 0,305141 \\
\hline $\mathrm{A}_{5}$ & 2 & 0,2 & 3 & 0,333333 & 1 & 0,832553 & 0,11201 \\
\hline
\end{tabular}

Таблиця 7. Порівняння альтернатив щодо критерію «Логічного мислення»

\begin{tabular}{|l|r|r|r|r|r|r|r|}
\hline Альтернативы & \multicolumn{1}{|c|}{$\mathrm{A}_{1}$} & $\mathrm{~A}_{2}$ & \multicolumn{1}{l|}{$\mathrm{A}_{3}$} & \multicolumn{1}{l|}{$\mathrm{A}_{4}$} & \multicolumn{1}{l|}{$\mathrm{A}_{5}$} & \multicolumn{1}{l|}{$\mathrm{K}_{i}^{\text {особ }}$} & \multicolumn{1}{l|}{$\gamma_{i j}$} \\
\hline $\mathrm{A}_{1}$ & 1 & 9 & 5 & 3 & 9 & 4,13918 & 0,56361 \\
\hline $\mathrm{A}_{2}$ & 0,111111 & 1 & 0,33333 & 0,33333 & 0,33333 & 0,33333 & 0,04538 \\
\hline $\mathrm{A}_{3}$ & 0,2 & 3 & 1 & 0,5 & 0,2 & 0,56967 & 0,07757 \\
\hline $\mathrm{A}_{4}$ & 0,333333 & 3 & 2 & 1 & 0,33333 & 0,92210 & 0,12555 \\
\hline $\mathrm{A}_{5}$ & 0,111111 & 3 & 5 & 3 & 1 & 1,37973 & 0,18787 \\
\hline
\end{tabular}


Таблиця 8. Порівняння альтернатив щодо критерію «Відповідальність»

\begin{tabular}{|c|c|c|c|c|c|c|c|}
\hline Альтернативы & $\mathrm{A}_{1}$ & $\mathrm{~A}_{2}$ & $\mathrm{~A}_{3}$ & $\mathrm{~A}_{4}$ & $\mathrm{~A}_{5}$ & $\mathrm{~K}_{i}^{\text {oco6 }}$ & $\gamma_{i j}$ \\
\hline $\mathrm{A}_{1}$ & 1 & 2 & 2 & 0,5 & 2 & 1,31950 & 0,24736 \\
\hline $\mathrm{A}_{2}$ & 0,5 & 1 & 2 & 0,5 & 0,5 & 0,75785 & 0,14207 \\
\hline $\mathrm{A}_{3}$ & 0,5 & 0,5 & 1 & 0,5 & 2 & 0,75785 & 0,14207 \\
\hline $\mathrm{A}_{4}$ & 2 & 2 & 2 & 1 & 2 & 1,74110 & 0,32640 \\
\hline $\mathrm{A}_{5}$ & 0,5 & 2 & 0,5 & 0,5 & 1 & 0,75785 & 0,14207 \\
\hline & & & & & сума & 5,33418 & \\
\hline
\end{tabular}

Таблиця 9. Порівняння альтернатив щодо критерію «Рівня активності»

\begin{tabular}{|c|c|c|c|c|c|c|c|}
\hline Альтернативы & $\mathrm{A}_{1}$ & $\mathrm{~A}_{2}$ & $\mathrm{~A}_{3}$ & $\mathrm{~A}_{4}$ & $\mathrm{~A}_{5}$ & $\mathrm{~K}_{i}^{\text {oco6 }}$ & $\gamma_{i j}$ \\
\hline $\mathrm{A}_{1}$ & 1 & 2 & 0,33333 & 0,11111 & 0,33333 & 0,47699 & 0,06154 \\
\hline $\mathrm{A}_{2}$ & 0,5 & 1 & 0,33333 & 0,11111 & 0,5 & 0,39202 & 0,05058 \\
\hline $\mathrm{A}_{3}$ & 3 & 3 & 1 & 0,5 & 5 & 1,86396 & 0,24049 \\
\hline $\mathrm{A}_{4}$ & 9 & 9 & 2 & 1 & 9 & 4,29290 & 0,55387 \\
\hline $\mathrm{A}_{5}$ & 3 & 3 & 0,2 & 0,11111 & 1 & 0,72478 & 0,09351 \\
\hline & & & & & сума & 7,75066 & \\
\hline
\end{tabular}

Таблиця 10. Порівняння альтернатив щодо критерію «Здібність вигадувати історії»

\begin{tabular}{|c|c|c|c|c|c|c|c|}
\hline Альтернативы & $\mathrm{A}_{1}$ & $\mathrm{~A}_{2}$ & $\mathrm{~A}_{3}$ & $\mathrm{~A}_{4}$ & $\mathrm{~A}_{5}$ & $\mathrm{~K}_{i}^{0006}$ & $\gamma_{i j}$ \\
\hline $\mathrm{A}_{1}$ & 1 & 2 & 0,14285 & 3 & 0,33333 & 0,77837 & 0,10931 \\
\hline $\mathrm{A}_{2}$ & 0,5 & 1 & 5 & 7 & 5 & 2,44569 & 0,34346 \\
\hline $\mathrm{A}_{3}$ & 7 & 0,2 & 1 & 5 & 3 & 1,83841 & 0,25818 \\
\hline $\mathrm{A}_{4}$ & 0,33333 & 0,14285 & 0,2 & 1 & 0,16666 & 0,27550 & 0,038692 \\
\hline $\mathrm{A}_{5}$ & 3 & 3 & 0,333333 & 6 & 1 & 1,78260 & 0,25034 \\
\hline & & & & & сума & 7,12058 & \\
\hline
\end{tabular}

Таблиця 11. Порівняння альтернатив щодо критерію «Здібність до оригінальної уяви»

\begin{tabular}{|c|c|c|c|c|c|c|c|}
\hline Альтернативы & $\mathrm{A}_{1}$ & $\mathrm{~A}_{2}$ & $\mathrm{~A}_{3}$ & $\mathrm{~A}_{4}$ & $\mathrm{~A}_{5}$ & $\mathrm{~K}_{i}^{0006}$ & $\gamma_{i j}$ \\
\hline $\mathrm{A}_{1}$ & 1 & 0,333333 & 0,2 & 0,2 & 0,14285 & 0,28573 & 0,03681 \\
\hline $\mathrm{A}_{2}$ & 3 & 1 & 5 & 7 & 5 & 3,49970 & 0,45091 \\
\hline$A_{3}$ & 5 & 0,2 & 1 & 0,333333 & 0,33333 & 0,64439 & 0,08302 \\
\hline $\mathrm{A}_{4}$ & 5 & 0,14285 & 3 & 1 & 2 & 1,337841 & 0,172371 \\
\hline $\mathrm{A}_{5}$ & 7 & 3 & 3 & 0,5 & 1 & 1,993711 & 0,256875 \\
\hline & & & & & сума & 7,761393 & \\
\hline
\end{tabular}

Розрахунок інтегральних показників за альтернативами згідно формули (5) зведемо в таблицю 12.

Таблиця 12. Інтегральні показники за альтернативами

\begin{tabular}{|l|l|l|l|l|l|l|l|l|l|l|l|l|l|}
\hline & $\mathrm{C}_{1}$ & $\mathrm{C}_{2}$ & $\mathrm{C}_{3}$ & $\mathrm{C}_{4}$ & $\mathrm{C}_{5}$ & $\mathrm{C}_{6}$ & $\mathrm{C}_{7}$ & $\mathrm{C}_{8}$ & $\mathrm{C}_{9}$ & \\
\cline { 2 - 12 } & \multicolumn{9}{|c|}{ Вага критеріїв } & \\
\cline { 2 - 12 } Альтер-нативи & 0,2811 & 0,0261 & 0,0697 & 0,1775 & 0,1071 & 0,4181 & 0,0722 & 0,0257 & 0,1656 & $\mathrm{Ri}$ \\
\hline $\mathrm{A}_{1}$ & 0,0372 & 0,0007 & 0,0112 & 0,0114 & 0,0604 & 0,1034 & 0,0044 & 0,0028 & 0,0061 & 0,24 \\
\hline $\mathrm{A}_{2}$ & 0,0266 & 0,0042 & 0,0064 & 0,0781 & 0,0049 & 0,0594 & 0,0037 & 0,0088 & 0,0747 & 0,27 \\
\hline $\mathrm{A}_{3}$ & 0,0182 & 0,0107 & 0,0420 & 0,0139 & 0,0083 & 0,0594 & 0,0174 & 0,0067 & 0,0138 & 0,19 \\
\hline $\mathrm{A}_{4}$ & 0,1050 & 0,0077 & 0,0023 & 0,0542 & 0,0135 & 0,1365 & 0,0400 & 0,0010 & 0,0285 & 0,39 \\
\hline $\mathrm{A}_{5}$ & 0,0942 & 0,0029 & 0,0074 & 0,0199 & 0,0201 & 0,0594 & 0,0068 & 0,0064 & 0,0425 & 0,26 \\
\hline
\end{tabular}


Зобразимо на рисунку порівняння отриманих альтернатив.

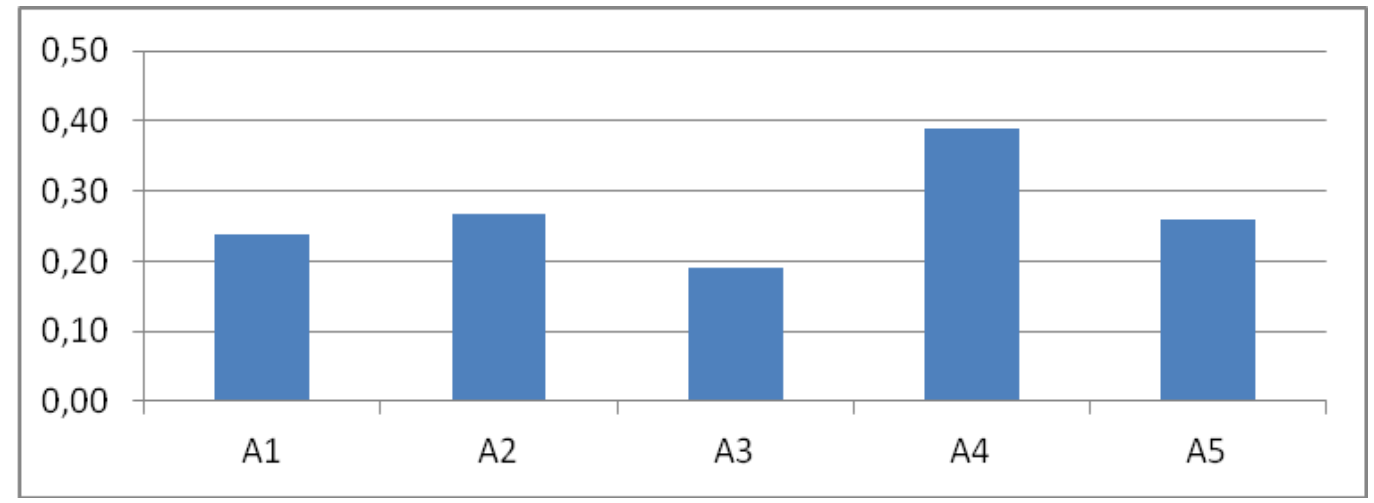

Рис. 2 Порівняння інтегральних показників оџінки напрямку розвитку дитини

Максимальне значення інтегрального показника відповідає альтернативі $\mathrm{A}_{4}$, що відповідає спортивному напряму розвитку.

Зауважимо, що експерти особливу увагу при виборі напрямку розвитку акцентували на умовах відповідальності, лідерських якостей, оригінальності уяви і товариськості (рис. 3). На думку психологів саме ці критерії $є$ визначальними у подальшому розвитку дитини.

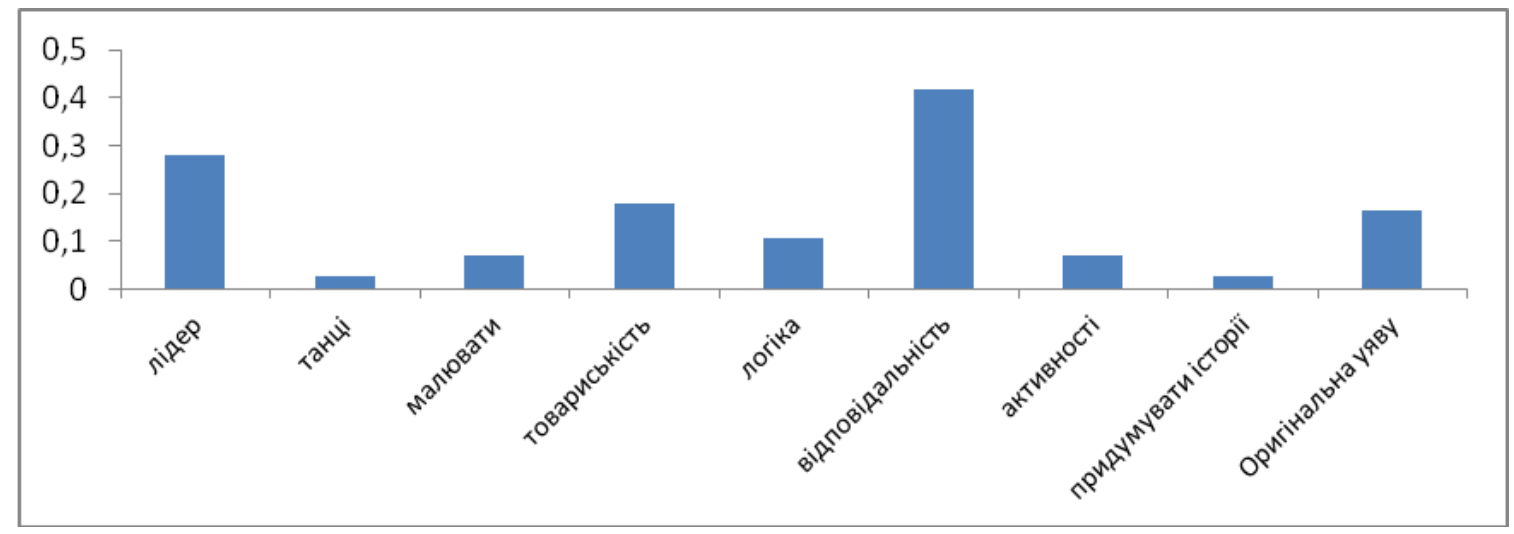

Рис. 3 Розподіл ваги впливу за критеріями

В результаті проведених досліджень, заснованих на вихідних даних; отриманих методом спостереження, можна зробити висновок, що для даної дитини пріоритетним напрямком розвитку $є$ спортивний напрямок. Однак необхідно зауважити, що музичне $\mathrm{i}$ гуманітарне спрямування також заслуговують у даному випадку на.

Висновки. На даний час існують дві точки зору на право застосування математики в психології. Одні стверджують, що математика - універсальний апарат до вирішення складних психологічних проблем. Найчастіше прихильники цієї думки зводять застосування математики до розрахунку статистичних даних за спостережуваним об'єктом. Прихильники іншої точки зору, навпаки, стверджують, що застосування математики в психології в принципі не можливо, бо на практиці моделювання та формалізація математичних явищ перетворюється в порожню гру математичними символами.

Узагальнюючи суперечливі точки зору на проблеми застосування математики в психології, вивчивши сучасні наукові напрямки в економіці, ми прийшли до висновку про можливість застосування принципів логістики в рішенні деяких задач психології.

Так, з нашої точки зору, потокові процеси в логістиці можливо спроектувати на потік інформації і знань в процесі розвитку і виховання дитини. Для управління потоковими процесами 3 метою мінімізації часу i фінансових коштів на їх формування $\mathrm{i}$ переміщення необхідне застосування математичних методів, що враховують системний підхід до виділених критеріїв.

В даній праці розглянуто задачу вибору напрямку розвитку дитини дошкільного віку на основі відомостей, отриманих методом спостереження. Дане завдання є багатокритеріальним, оскільки останнім часом склалася думка про необхідність різнобічного розвитку дитини без урахування іiї індивідуальних здібностей. 
Для вирішення поставленого завдання запропоновано використання математичного апарату Аналізу аналітичних ієрархій з метою виділення пріоритетних напрямків розвитку.

Даний метод дозволяє:

- провести багатокритеріальний аналіз проблеми вибору;

- врахувати і порівняти за важливістю різнопланові показники, використовуючи експертні оцінки;

- визначити порядок пріоритетів;

- $\epsilon$ системним, призначеним для вирішення системних проблем, зокрема вибору напрямку розвитку дитини.

У результаті експериментального прикладу, при використанні методу аналізу ієрархій, були отримані рекомендації щодо можливих напрямків розвитку дитини.

\section{ЛIТЕРАТУРА}

1. Асмолов А.Г. Как проектировать универсальные учебные действия в начальной школе: от действия к мысли [Текст]: пособие для учителя / А.Г. Асмолов, Г.В. Бурменская, И.А. Володарская и др. М.: Просвещение, 2008. - 151 с.

2. Гулина М.А. Консультативная психологи [Текст] / М.А. Гулина, Ю.П. Зинченко - СПб.: Питер, 2015. - $336 \mathrm{c}$.

3. Обухова А.С. Психолого - педагогическое взаимодействие участников образовательного процесса [Текст]: ученик и практикум для СПО / А.С. Обухова - Издательство Юрайт, 2008. - 422 с.

4. Залевский Г.В. Самореализация личности: системный взгляд [Текст] / Г.В. Залевский, В.Е. Клочко, Э.В. Галажинский / Томск: Издательство Томского университета, 1999. - 154 с.

5. Michael E.D. (2018) What is KM? Knowledge Management Explained [Електронний ресурс]. - Режим доступу: http://www.kmworld.com/Articles/Editorial/What-Is/What-is-KM-Knowledge-ManagementExplained-122649.aspx

6. Саати Т.Л. Принятие решений: Метод анализа иерархий [Текст] / Т. Л. Саати; Переводчик Р. Г. Вачнадзе. - М.: Радио и связь, 1993. - 314 с. 